数がプラトーに達する. また, 高いX線エネルギーでは, 光子に対 する質量減弱係数が小さいこと, 肺ファントムからの 2 次電子の飛 程が長いことから, 電離箱壁からの 2 次電子の影響は少ないと考え られる。

\section{0 発表取り下げ}

191 強度変調放射線治療(IMRT)に用いる積層補償フィル夕の基 礎的検討

袋井市立袋井市民病院・診療技術部 佐々木浩二, 小嶋 友 小栗徳彦，毛受義孝，戸倉一美

【目的】補償フィル夕を用いて照射野内の放射線強度を変化させる強 度変調放射線治療は，オープンビームによる連続照射であるため, 精度管理の容易さと既存の加速器でのIMRTの実現を可能とするも のと考えられており，現在，装置等の制限によりIMRTを行えない 治療施設においても高度な放射線治療が行える可能性がある。これ に対応した吸収体積層型の補償フィル夕を用いる場合における, フィルタ材料によって起こる線質の変化や半影などについて基礎的 検討を行ったので報告する。

【方法】測定には水ファントム・水等価固体ファントムおよび， Film と指頭型電離箱を用いた。使用ビームは, $4 \mathrm{MV} \cdot 10 \mathrm{MV} \mathrm{X}$ 線であ り, 放射線治療計画装置はPinnacle3 使用した。 今回は, 種々の照 射野パターンにおける, RTPsでの線量分布計算結果と実際の線量分 布の整合性について検討した。

【結果】フィル夕材料による吸収は，半価層で $1.38 \mathrm{~cm}(4 \mathrm{MV}), 1.23 \mathrm{~cm}$ (10MV)であり，隙間を補填するポリエチレン材による吸収は，5 cm厚で5.28\% (4 MV), 3.76\% (10MV)であった. RTPsの計算值は実 測值との間に乘離が見られ, 密度の值を変更して良好な結果が得ら れた。しかし, 吸収体の形状を変化させて色々な形状で検討した結 果, 吸収体厚が小さい線量の大きな部分での差が大きくなった。ま た，PDDでは 4 MVでBeam hardeningによる変化が見られた。 【考察】計算值と実測值との誤差の原因は, RTPsでは 1 次線TERMA 分布や散乱KernelにOpen beamのデータが適用されており, Modulator によるエネルギー分布や照射野の変化が適切に反映されていないた めと考えられる. Beam hardeningの影響と単位厚さあたりの吸収の 大きさによる線量変化の自由度を考慮すると, エネルギーは10MV がbetterであると考えられる。

192 不均質積層型ファントムによる炭素線の減弱量評価 北里大学大学院・医療系研究科 真柄昂胤, 丸山浩一 独立行政法人国立病院機構東京医療センター・放射線科喜久村力 【目的】放医研では炭素線による癌治療が良好な成績を得ている。従 来の光子線・電子線治療に比ベブラッグピークを持つため線量集中 性が優れ，高RBEという利点があるが，炭素線の人体内での核破砕 反応による減弱量評価が課題となっている. 現在の炭素線治療計画 においては体内線量分布計算には実測した水中深部線量分布が使用 されており，骨などの物質中での核破砕反応の影響は考慮されてい ない. 本研究の目的は治療部位の不均質性を考虑した積層型ファン トムを製作し，水ファントムの結果と比較することである。これに より水ファントムを使用することの正当性を検証する。

【方法】ファントムは炭素線の適応が多い肺癌と前立腺癌を想定し, CT画像を再現するように設計した。測定装置は製作したファントム の前方に核種同定用検出器である $\Delta \mathrm{E}$ 配置し, ファントムの周囲 を覆う破砕粒子検出器で構成されている。 $\Delta \mathrm{E}$ 及び破砕粒子検出器 は全てプラスチックシンチレータ製である。炭素線のエネルギーは 肺癌では $200 \mathrm{MeV} / \mathrm{u}$, 前立腺癌では $250 \mathrm{MeV} / \mathrm{u}$ を使用した。不均質 ファントムでの減弱量と水ファントムでの減弱量を比較した。

【結果・考察】それぞれのファントムでの減弱量は, 前立腺癌ファン
トムで $31.1 \%$ となり，水の $31.4 \%$ とほぼ同じ結果を得た。一方，肺癌 ファントムでは $23.2 \%$ ，水で $20.3 \%$ となり約 $3 \%$ の差が見られた. 【結論】肺がんの場合, 治療部位の不均質性を考慮した積層型ファン トムと水ファントムによる炭素線の隇弱量には差が見られた，水 ファントムを使用することの正当性については，今後さらに詳細な 検討を進める予定である。

193 治療用X線照射により生成される陽電子数の評価 北里大学大学院·医療系研究科 松林史泰，丸山浩一 千葉大学医学部附属病院・放射線部 橋本成世

【目的】1.022 MeV以上の光子を物質に入射すると電子・陽電子対生成 により電子と陽電子が生成される，従って治療用X線を人体に照射 すると陽電子が生成されると推定できる．本研究の目的は，治療用 X線の照射により生成される陽電子の量を理論的に評価することで ある。

【方法】X線治療に用いられるリニアックから発生する光子数を，1電 流パルスのパルス幅とピーク電流, 光子の発生効率を用いて算出し た。また，Kramersの式を用いて10MVX線のエネルギースペクトル を算出した。これらの結果を用いて，1電流パルスで発生するX線 のエネルギースペクトルを作成した．Hubbellが報告した質量電子対 減弱係数デー夕を用いて, 光子エネルギーと水中での陽電子生成割 合の関係を得た，水中で陽電子が一様に生成されると仮定したとき の 1 電流パルス中での生成陽電子数を導出した.

【結果と考察】ピーク電流が $100 \mathrm{~mA}$ のき， 1 電流パルスあたり $5.6 \times 10^{11}$ 個の光子が発生すると算出され，10MVX線を $10 \mathrm{~cm}$ 厚さの水 ファントムに照射すると， $6.8 \times 10^{9}$ 個の陽電子が生成されると導出で きた，人体の $70 \%$ は水で構成されているので，X線治療時に多くの 陽電子が人体で生成される。人体で生成陽電子数を評価するため に，骨などで生成される陽電子数を評価する必要がある。また，生 成陽電子数の位置依存性を評価する必要がある。モンテカルロシ ミュレーション法を用いてこれらの評価を行い，人体で生成される 陽電子数を導出できた。生成された陽電子は人体内で電子と結合し て消滅するので，消滅 $\gamma$ 線を外部で検出することができればX線照射 領域測定の可能性がある.

【結論】治療用X線の照射により水中で生成される陽電子の量を理論 的に評価した，また，治療用X線照射により，多くの陽電子が人体 で生成される。

194 放射線治療計画へのPET-CT利用の基礎検討 (3)一幾何学的 精度について一

国立がんセンター東病院・放射線部 池田 剛，佐藤 敬，高田敦子 福原里恵, 大山正哉，勝田昭一，荻野 尚 GE横河メディカルシステム 平山 昭

【はじめに】FDG-PETの集積分布はその腫瘍における悪性度を反映し ていると言われている. CTの形態画像とPETの機能画像による正確 な重ね合わせ表示 (fusion imaging)により，癌浸潤範囲を把握するこ とが可能であるが，PETの集積を利用して腫湯に対して十分な線量 の投与が可能となるためには, PET-CT装置の幾何学的精度が保証さ れていなければならない。

【目的】PET-CT装置は診断装置であり，その画像デー夕を治療計画で 使用する際に, その幾何学的精度が重要となってくる. 今回我々 は, 治療計画に利用するためPET-CTのQAを行い, 特にPETとCT画 像中心がどの程度正確に一致するのか検証したので報告する。

【方法】直径 $1 \mathrm{~mm}$ の点線源を用い撮影中心を設定し, CT撮影を行っ た。次に，PET側にスライドして寝台を $0.5 \mathrm{~mm}$ 体軸方向に移動させ ながら，撮像を行ったＳSSPを用いて両デー夕の装置間における中 心の䛊差を測定した。

【結果及び考察】測定結果からCTとPET間の体軸方向, 横方向, 高さ 